\title{
Perilaku Menyalip
}

\author{
Hartanto $^{1}$ \\ Fakultas Psikologi Universitas Widya Dharma
}

\begin{abstract}
Traffic accidents due to overtaking other vehicles can cause serious injuries and even death. This research attempted to explain the effect of spatial cognition in driver when decided to overtake by investigating the characters (risk-taking and risk averse), visual types (fast and slow) and motorcycle types (manual, matic, and motor bebek). Twenty three people participated in the study. Participants conducted simulation on PsychoPy. Three-way Anova was executed and resulted in 1) as predicted by theory, risk taking subjects had faster spatial cognition than risk averse subjects $(\mathrm{F}=8.083, \mathrm{p}=0.005)$. 2) There was significantly different effect among visual types $(\mathrm{F}=16.459, \mathrm{p}=7.45 \mathrm{e}-05)$. 3) Interaction effect was significant at factor character and visual types $(\mathrm{F}=6.881, \mathrm{p}=0.009)$. 4) Main interaction effect yielded similar result $(\mathrm{F}=7.774, \mathrm{p}=0.005)$. Average probabilities road accident naturally increased paralel with intention to overtake frequency. Moreover, high chance to overtake allegedly came from individual with risk taking character, fast visual type and riding motor bebek.
\end{abstract}

Keywords: driving; spatial cognition, traffic psychology

\begin{abstract}
Abstrak. Kecelakaan lalu lintas yang disebabkan oleh perilaku menyalip dapat menyebabkan cedera serius dan bahkan hilangnya nyawa. Penelitian ini mencoba menjelaskan efek dari kognisi spasial pengemudi dengan menginvestigasi karakter (risk-taking dan risk-averse), tipe tatapan (cepat dan lambat) dan jenis motor (manual, matic, dan bebek). Hasil anava 3 jalur, 1 ) sesuai teori, individu risk taking memiliki kognisi spasial lebih cepat dari risk averse $(F=8,083$, $p=0,005)$. 2) Ada efek signifikan antara tipe tatapan $(F=16,459, p=7,45 \mathrm{e}-05)$. Interaksi signifikan pada level karakter dan jenis tatapan $(F=6,881, p=0,009)$. 4) Interaksi utama juga signifikan $(F=7,774, p=0,005)$. Rata-rata peluang kecelakaan naik seiring seringnya perilaku menyalip di jalan raya. Lebih dari itu kelompok yang memiliki peluang tinggi untuk menyalip adalah yang memiliki karakter risk taking, tipe visual cepat, dan mengendarai motor bebek.
\end{abstract}

Kata kunci: kognisi spasial; psikologi lalu lintas; berkendara

Dalam beberapa tahun belakangan ini, kecelakaan lalu lintas diakibatkan tabrakan motor dengan korban jiwa luka ringan (lecet), berat (kehilangan anggota badan, patah tulang) dan bahkan kematian menunjukkan kenaikan data yang fantastis. Indonesia menempati posisi tinggi diantara rata-rata kecelakaan lalu lintas diantara negara ASEAN. Data oleh Jenderal Royke
Lumowa dari Kepolisian Republik Indonesia yang menjabat sebagai Kepala Korps Lalu Lintas Kepolisian Indonesia (Korlantas Polri) menyebutkan bahwa ada sekitar 28-30 ribu nyawa melayang di jalan akibat kecelakaan (Rusmin, 2017).

Memiliki motor atau mobil dan mengendarainya di jalan raya bukan berarti tidak membutuhkan satu set

\footnotetext{
${ }^{1}$ Korespondensi artikel ini dapat dilakukan melalui hartantopaud@unwidha.id
} 
kemampuan khusus. Jika aturan ini dilanggar maka kecelakaanlah yang akan terjadi. Beberapa studi secara global, secara intensif berusaha mengurangi angka laka ini dengan pendekatan tehnologi (Li, Qiao, Wang \& Yu, 2017), dan membuat regulasi menjadi lebih ketat (Wali, Ahmed, Iqbal, \& Hussain, 2017). Dari data yang didapatkan di lapangan, kecelakaan lalu lintas terjadi karena berbagai faktor dan faktor yang menyumbang paling besar (sekitar 80\%) adalah faktor pengemudi atau pengendara. Walaupun juga ada kontribusi laka itu dari beberapa pengemudi yang baru belajar, namun hampir mayoritas laka muncul karena keteledoran sang pengemudi. Keteledoran bisa berarti menyetir dengan melakukan texting/chat, tidak fokus misalnya mengantuk, letih, capek, aggressive driving (Stephens, \& Groeger, 2012) atau memang terlalu berani (kurang memiliki perhitungan melihat kondisi lapangan) dalam mengambil risiko misalnya tidak sabar dan agresif (Cole, 2017; Ma, Hao, iang \& Yan, 2018).

Di Indonesia sendiri Kepolisian Republik Indonesia juga tidak hentihentinya mengupayakan berbagai cara untuk semakin meminimalisir angka kecelakan lalu-lintas, salah satunya dengan melakukan screening test atau asesmen psikologi (nugroho, 2018). Namun menurut peneliti tes psikologi yang tepat untuk diaplikasikan dalam misalnya pembuatan SIM adalah tes yang langsung menyasar atau mengukur abilitas dari peserta asemen, disamping juga ada asesmen psikologis secara umum. Dimana ide itu menjadi tujuan dari penelitian ini yaitu memberikan pendekatan baru yang mampu diaplikasikan untuk membantu memberikan data yang lebih detail mengenai perilaku dijalan raya mengenai kecepatan respon reaksi. Pada ranah neurosains atau skala neuron, kecepatan dalam bereaksi dan memutuskan diukur menggunakan ukuran waktu mil/second (ms) (Bob, 2011).

Dalam psikologi lalu lintas ada sejumlah teori besar mengulas mengenai kontribusi atensi, memori, dan tentu saja spatial cognition pada perilaku mengendarai kendaraan bermotor (Trif, 2015). Spatial cognition merupakan kemampuan dalam membuat terkaan ketika di jalan raya, maintaining dan fokus pada beberapa stimulus termasuk jarak dan kecepatan, melakukan kontrol diri dan berpindah dari satu atensi objek ke yang lain (Walshe, McIntosh, Romer, \& Winston, 2017). Kognisi spasial di atas apabila sudah otomatis menjadi ability yang menetap. Salah satu ability yang sangat penting karena mutlak menentukan keselamatan pengendara dalam mengemudi mobil/ motor adalah mendahului kendaraan lainnya/menyalip. Apabila fungsi eksekutifnya bagus dan bekerja secara sempurna otomatis kemampuan spasialnya dalam melakukan prediksi seperti ketika memutuskan untuk melakukan penyalipan (overtaking) akan tepat dan begitu juga sebaliknya. Banyak sekali laka fatal yang terjadi karena gagalnya ketika mendahului kendaraan, dengan kata lain sang pengemudi salah dalam melakukan taksiran jarak, mengenai kecepatannya, kecepatan kendaraan yang ingin didahului, laju kendaraan dari depan dan kontur atau kondisi jalan tempat menyalip. Mempercepat kendaraan ketika lampu kuning juga lazim dilakukan oleh masyarakat kita, yang di mana di satu sisi memutuskan berhenti mendadak juga bukan keputusan yang tepat. Untuk membuat baseline mengenai kecepatan respon dalam membuat keputusan apakah melakukan penyalipan atau tidak inilah yang memberikan banyak detail data yang dibutuhkan dalam pengembangan asesmen psikologi.

Kognisi spasial dalam berkendara di jalan raya dari dugaan peneliti bervariasi 
tiap karakter. Misalkan karakter individu yang cenderung menyukai sensasi dan risiko akan lebih memiliki frekuensi menyalip dan mengejar lampu hijau lebih tinggi daripada individu dengan karakter menjauhi risiko. Perilaku berisiko (risk taking) merupakan satu set perilaku dan belief/keyakinan yang muncul untuk menanggung risiko/loss ketika menghadapi dan memutuskan akan sesuatu yang tidak pasti (uncertainty) (Groot \& Thurik, 2018). Sedangkan perilaku tidak berisiko adalah kebalikannya (risk averse). Pengendara kendaraan bermotor akan diberikan pilihan dengan risiko yang bervariasi, namun semua tetap memiliki tujuan yang sama yaitu selamat sampai ditujuan. Setiap pilihan ini dapat memberikan keuntungan ataupun kerugian yang tidak sama (berbelok, menerobos lalin, sampai menyalip).

Kondisi di jalan setiap saat mengalami perubahan, dan menurut teori TCI (Task Capability Interface) kemampuan mengemudi adalah kemampuan yang frekuensinya sangat sering diasah antara kapabilitas sang pengemudi itu sendiri dengan tantangan di jalan (Fuller, 2011). Dengan begitu mengemudi di jalan itu dapat diartikan sebagai memutuskan sesuatu dibawah kondisi tidak pasti. Misalnya hari ini Tono mengendarai sepeda motor dan berada di jarak 50 meter dengan lampu kuning, Tono mengerem karena kondisi di depan ada satu buah mobil, namun keesokan harinya Tono berada di jarak 100 meter dan lampu kuning, anehnya Tono malah mempercepat laju kendaraan karena di depan hanya ada 3 motor. Ilustrasi di atas hanya contoh kecil dari realitas mengendarai kendaraan bermotor, di mana sangat tidak pasti dan keputusan dibuat saat itu juga dan dituntut untuk sangat akurat. Ilustrasi pertama Tono memutuskan untuk menjadi save player, sedangkan kedua Tono menjadi risk taking. Literatur mencatat bahwa populasi yang memiliki tingkat risiko tertinggi dalam beberapa hal termasuk mengendarai mobil adalah individu dengan umur remaja dan dewasa muda (Leather, 2009).

Dari ADReS (Assement of Driving Related-Skill) dan TMT (Test Making Trail) (Ott, David, Papandonatos, Hewitt, Festa, Heindel, Snellgrove \& Carr, 2013), ternyata keterampilan mengendarai sepeda motor berkaitan dengan jenis visual search dari pengendara. Di jalan aturan baku yang harus dipahami pengendara adalah harus fokus pada rambu-rambu dan memperhatikan pengguna jalan yang lain, namun berbalik dengan aturan tersebut, ironisnya hanya di jalan inilah banyak sekali orang menjajakan barang dan jasa. Hasilnya adalah banyak sekali distraksi ketika orang mengendari motor di jalan. Ketika pengemudi sedikit saja tidak memberikan atensi atau terdistraksi atensinya pada kondisi lalu lintas maka dapat terjadi kecelakaan (Pope, Bell, \& Stavrinos, 2016).

Berbekal fakta tersebut di atas peneliti ingin mengurai tentang dinamika visual search lebih tepatnya search asymmetries (Wolfe, 2018) dari pengemudi ketika beraksi di jalan. Visual search merupakan kemampuan spasial individu untuk melakukan kalkulasi mengenai perubahan/threshold kondisi lingkungannya secara visual dan memutuskan mana yang harus lebih dahulu diproses (Huang \& Pashler, 2005).

Visual search ini merupakan cara yang digunakan manusia dalam kesehariannya, dari tugas yang mudah seperti misalnya memilih makanan, medium memilih rute jalan dan berat yang melibatkan refleksi filsafat seperti memilih pasangan dan mempercayai seseorang (Eckstein, 2011). Visual search rencananya akan dibagi menjadi 2 yaitu tipe fast search dengan sasaran dan tipe slow search dengan sasaran yang dibedakan dengan threshold waktu. 
Beberapa sudah diuraikan mengenai faktor internal, kenyataan di lapangan ada beberapa faktor eksternal yang memiliki kontribusi dalam perilaku mengendarai kendaraan, salah satunya adalah tipe dari kendaraan. Tipe kendaraan mayoritas terbagi atas mobil dan motor. Mobil memiliki bentuk yang berbeda dengan motor, sehingga cara mengemudi mobil dan motor juga mengalami perbedaan, di mana motor terbagi menjadi setidaknya 3 tipe yaitu motor kopling bebek-otomatis, motor kopling manual dan motor tanpa kopling alias matic. Dengan model yang berbeda akan memberikan gaya mengemudi yang berbeda pula, seperti motor kopling manual selalu identik dengan motor laki jadi pengemudi akan memposisikan sebagai pengendara yang jantan, macho yang berimbas pada penggunaan kecepatan yang di atas ratarata.

Berbeda lagi pada jenis motor kopling otomatis yang dilabeli motor cewek atau "bebek". Pengendara dengan motor cewek cenderung kalem dan pelanpelan. Yang terakhir adalah tipe matic di mana individu yang menggunakan tipe ini merepresentasikan karakteristik dan siftat yang: ramping, gesit, instan, stop and go, dan mudah pengunaannya. Akibatnya pengemudi dengan motor ini cenderung melakukan zig-zag dengan melintasi lane pengendara yang lain, buru-buru dan menganggap mudah perilaku mengendarai sepeda motor di jalan.

Penelitian ini terbagi menjadi 4 hipotesis yaitu: 1) menguji beda pengaruh antara karakter risk taking dengan risk averse terhadap waktu reaksi kognisi spasial. 2) Melihat dan menguraikan keterkaitan antara tipe fast visual search dengan slow visual search terhadap waktu reaksi kognisi spasial. 3) Melihat kontribusi dari faktor eksternal khususnya tipe kendaraan bermotor pada waktu reaksi kognisi spasial. 4) Terakhir, menguji interaksi antara model teori dan telaah peneliti terhadap data faktual dilapangan. Secara umum, penelitian pionir ini akan memberikan pemahaman mengenai kognisi spasial dan variable-variabel yang berkaitan ketika menyalip dijalan raya. Secara khusus, akan memberikan kontribusi fakta dan data untuk kemajuan psikologi lalu lintas di Indonesia.

\section{Subjek}

Subjek penelitian terdiri dari 30 orang terdiri dari berbagai macam elemen, yaitu mahasiswa dan non-mahasiswa. Subjek sebelum mengikuti eksperimen juga diberi inform consent yang menandakan persetujuan berpartisipasi dalam penelitian. Setelah dilakukan pengelompokan, eksperimen dilakukan dalam 1 kelas/ruangan eksperimen dan subjek masuk secara berurutan. Subjek dalam kondisi sehat dan tidak mengalami cacat apapun.

\section{Metode}

Penentuan karakter risk taking dan risk averse dilakukan dengan BART (Lejuez, Richard, Read, Kahler, \& Ramsey, 2002; Fukunaga, Brown, \& Bogg, 2012) memakai Psychopy (Pierce \& MacAskill, 2018). Penentuan level dari visual scanning dilakukan melalui mean dari waktu reaksi pada 12 trial $\mathrm{R}$ or B Task. Pengukuran kognisi spasial menggunakan image yang dikumpulkan oleh peneliti dan dipresentasikan menggunakan Python (van Rossum, 1995) dan Expyriment (Krause, \& Lindemann, 2014). Image memiliki resolusi 1440x900 pixel dan kualitasnya 720p mengenai kondisi di jalan raya. Analisis data menggunakan ANOVA Faktorial 3 jalur dengan rincian 3 variabel independent/factor ( $2 \times 2$; berisiko vs tidak berisiko, 2x2; fast search ws slow search, 2x3; manual vs bebek vs matic) dengan kognisi spasial RT (waktu reaksi) sebagai variabel 
tergantung (lihat tabel 1). Piranti lunak yang dipakai adalah $\mathrm{R}$ ( $\mathrm{R}$ core team, 2013) untuk melakukan manajemen dan analisis data. Package ggplot2 (Wickham, 2016) sangat berperan penting dalam memproduksi grafik dari hasil analisis data.

Tabel 1.

Formasi Variabel

\begin{tabular}{|c|c|c|c|c|}
\hline \multirow{2}{*}{\multicolumn{2}{|c|}{$\begin{array}{c}\text { Karakter / } \\
\text { Visual }\end{array}$}} & \multicolumn{3}{|c|}{ Tipe Motor } \\
\hline & & Manual & Bebek & Matic \\
\hline \multirow{3}{*}{ Risk Taking } & \multirow{2}{*}{ Fast Search } & overtakel & overtakel & overtakel \\
\hline & & non-overtake & non-overtake & non-overtake \\
\hline & \multirow{2}{*}{ Slow Search } & overtakel & overtakel & overtakel \\
\hline \multirow{3}{*}{ Risk Averse } & & non-overtake & non-overtake & non-overtake \\
\hline & Fast Search & $\begin{array}{c}\text { overtakel } \\
\text { non-overtake }\end{array}$ & $\begin{array}{c}\text { overtakel } \\
\text { non-overtake }\end{array}$ & $\begin{array}{c}\text { overtakel } \\
\text { non-overtake }\end{array}$ \\
\hline & Slow Search & $\begin{array}{c}\text { overtakel } \\
\text { non-overtake }\end{array}$ & $\begin{array}{c}\text { overtakel } \\
\text { non-overtake }\end{array}$ & $\begin{array}{c}\text { overtakel } \\
\text { non-overtake }\end{array}$ \\
\hline
\end{tabular}

\section{Hasil}

Dari 30 subjek penelitian, hanya sekitar 23 yang bisa memenuhi syarat untuk lanjut penelitian. Klasifikasi karakter risk taking dan risk averse memakai BART daripada IGT karena lebih mudah dan familiar dibandingkan IGT (Balaguero, Vicente, Molina, Tormos, \& Rovira, 2015). Bart dilakukan modifikasi nominal dan currency-nya dalam rupiah. Total sebanyak 9 orang memiliki kecenderungan pada perilaku mencari risiko dan sebanyak 11 orang tidak menyukai risiko. Pengukuran pengklasifikasian berdasarkan jumlah spasi yang ditekan dan balon yang meletus dalam 20 kali trial. Untuk visual search (fast vs slow) peneliti memakai try out untuk mencari titik imbang untuk penentuan klasifikasi waktu reaksi. Titik batas adalah sekitar 2000 - 5000 ms dengan kategori cepat dan 6000-10000 ms dengan kategori lambat. Dari hasil tersebut diperoleh sekitar visual fast dalam karakter risk taking sebanyak 7 orang, fast visual search dalam kelompok karakter risk averse sebanyak 4 orang, slow visual search pada kelompok berisiko sebanyak 2 orang, dan visual slow pada kelompok tidak berisiko sebanyak 7 orang. Pada tipe kendaraan bermotor terdapat 9 subjek yang memakai kendaraan bermotor tipe matic, sebanyak 7 subjek memakai kendaraan motor tipe bebek atau step-through dan sisanya tipe motor sport 
Tabel 2.

Karakter Risk Taking

\begin{tabular}{lccccccr}
\hline $\begin{array}{c}\text { Tipe } \\
\text { motor }\end{array}$ & $\begin{array}{c}\text { Tipe } \\
\text { visual }\end{array}$ & Menyalip & \% & Mean RT & $\begin{array}{c}\text { Tidak } \\
\text { menyalip }\end{array}$ & \% & Mean RT \\
\hline Manual & Fast & 11 & $91.6 \%$ & 9669 & 1 & $8.3 \%$ & 1109 \\
Bebek & Fast & 22 & $91.6 \%$ & 14737 & 2 & $8.3 \%$ & 1868 \\
Matic & Fast & 44 & $91.6 \%$ & 38873 & 4 & $8.3 \%$ & 4734 \\
Manual & Slow & 9 & $75 \%$ & 37966 & 3 & $25 \%$ & 4637 \\
Bebek & Slow & 18 & $75 \%$ & 31682 & 6 & $25 \%$ & 10221 \\
Matic & Slow & 12 & $50 \%$ & 60664 & 12 & $50 \%$ & 41368 \\
\hline Total & & $\mathbf{1 1 6}$ & $\mathbf{8 0 . 5 \%}$ & & $\mathbf{2 8}$ & $\mathbf{1 9 . 4 \%}$ \\
\hline
\end{tabular}

Tabel 3.

Karakter Risk Averse

\begin{tabular}{lcccrcrr}
\hline $\begin{array}{c}\text { Tipe } \\
\text { motor }\end{array}$ & $\begin{array}{c}\text { Tipe } \\
\text { visual }\end{array}$ & Menyalip & $\mathbf{\%}$ & Mean RT & $\begin{array}{c}\text { Tidak } \\
\text { menyalip }\end{array}$ & $\%$ & Mean RT \\
\hline Manual & Fast & 5 & $41.6 \%$ & 4716 & 7 & $58.3 \%$ & 7635 \\
Bebek & Fast & 12 & $50 \%$ & 16771 & 12 & $50 \%$ & 18347 \\
Matic & Fast & 6 & $50 \%$ & 37982 & 6 & $50 \%$ & 16741 \\
Manual & Slow & 12 & $50 \%$ & 27951 & 12 & $50 \%$ & 28689 \\
Bebek & Slow & 17 & $47.2 \%$ & 60664 & 19 & $52.7 \%$ & 56840 \\
Matic & Slow & 13 & $54.2 \%$ & 40414 & 11 & $45.8 \%$ & 31463 \\
\hline Total & & $\mathbf{6 5}$ & $\mathbf{4 7 . 4 \%}$ & & $\mathbf{6 7}$ & $\mathbf{4 9 \%}$ & \\
\hline
\end{tabular}

Tabel 4.

Kategorisasi Tipe Partisipan

\begin{tabular}{cccccccc}
\hline Karakter & Visual & Motor & Total & Karakter & Visual & Motor & Total \\
\hline Risk Taking & Fast & Manual & 1 & Risk Taking & Slow & Manual & 1 \\
Risk Taking & Fast & Bebek & 2 & Risk Taking & Slow & Bebek & 2 \\
Risk Taking & Fast & Matic & 4 & Risk Taking & Slow & Matic & 2 \\
Risk Averse & Fast & Manual & 1 & Risk Averse & Slow & Manual & 2 \\
Risk Averse & Fast & Bebek & 2 & Risk Averse & Slow & Bebek & 3 \\
Risk Averse & Fast & Matic & 1 & Risk Averse & Slow & Matic & 2 \\
\hline Total & & & $\mathbf{1 1}$ & & & & $\mathbf{1 2}$ \\
\hline
\end{tabular}

search ditemukan hasil yang signifikan juga di mana nilai $p$ untuk null hipotesis terlalu kecil untuk menolak ada beda $(F$ value $=16.495$ dan $p=7.45 \mathrm{e}-05(p<0.01)$. Analisis post-hoc ditemukan beda antara slow visual search dengan fast visual search $($ diff $=1505.245$, lwr $=923.8414$, upr $=$ 2086.649, $p=7 \mathrm{e}-07 ; p<0.01)$. Nilai positif menunjukkan pada mean pada kelompok slow visual memiliki waktu reaksi lebih besar dibandingkan dengan kelompok fast visual search. 3) Main effect terakhir adalah pada kelompok jenis motor yang dipakai. Dari hasil analisis ternyata tidak ada perbedaan kecepatan waktu reaksi ketika menyalip antara tipe motor dengan nilai $F$ value $=2.577$ dan $p$ value $=0.079022(\mathrm{p}<$ 0.001). Hasil ini berbeda dengan tinjauan rasionalis peneliti di mana sepeda motor tipe matic karena mudah digunakan maka siapapun yang naik akan berperilaku sesuai dengan "tema" motor tersebut yaitu lincah dan gesit. 4) Pada tahap efek interaksi antara karakter dengan visual terdapat hasil yang signifikan dengan nilai $F=6.881$, dan $p$ value $=0.009509$. Dari kombinasi interaksi antara kelompok karakter dengan tipe visual hanya ada 3 
dari total 6 perbandingan kelompok yang signifikan. Perbandingan kelompok dengan karakter risk taking - visual slow terhadap karakter risk taking - visual fast memiliki nilai diff $=2637.1893$, lwr $=$ 1211.9362, upr $=4062.442$, dan $p=$
0.0000204. Disusul oleh kelompok risk averse - visual slow dengan risk taking visual fast dengan nilai diff $=2217.3484$, lwr $=826.2939$, upr $=3608.403$ dan nilai $p=$ 0.0003218 .

Tabel 5.

Perhitungan Anava 3 Jalur Perilaku Menyalip

\begin{tabular}{lcrrrr}
\hline & $d f$ & Sum Square & Mean Square & \multicolumn{1}{c}{ F value } & P value \\
\hline karakter & 1 & $6.313 \mathrm{e}+07$ & 63134426 & 8.083 & 0.005019 \\
visual & 1 & $1.288 \mathrm{e}+08$ & 128831692 & 16.495 & $7.45 \mathrm{e}-05$ \\
motor & 2 & $4.025 \mathrm{e}+07$ & 20124118 & 2.577 & 0.079022 \\
karakter:visual & 1 & $5.374 \mathrm{e}+07$ & 53743298 & 6.881 & 0.009509 \\
karakter:motor & 2 & $3.100 \mathrm{e}+07$ & 15502179 & 1.985 & 0.140602 \\
visual:motor & 2 & $5.867 \mathrm{e}+06$ & 2933591 & 0.376 & 0.687453 \\
karakter:visual:motor & 2 & $1.214 \mathrm{e}+08$ & 60721763 & 7.774 & 0.000589 \\
Residuals & 169 & $1.320 \mathrm{e}+09$ & 7810548 & & \\
\hline
\end{tabular}

Terakhir, perbandingan kelompok karakter risk taking - visual fast dengan risk averse - visual slow dengan nilai diff = 1935.7970, lwr $=-3658.9800$, upr $=-212.614$ dan nilai $p=0.0208671$. Efek interaksi terakhir yang melibatkan 3 faktor (karakter, visual dan motor) terbukti signifikan dengan nilai $F=7.774$, dan $p$ value = 0.000589. Perbandingan antar kelompok sebanyak 66 kelompok ditemukan sebanyak 6 kelompok yang terbukti signifikan, yaitu kelompok risk averse visual fast - matic : risk taking - visual fast manual dengan nilai diff $=5451.333333$, lwr $=750.14667$, upr $=10152.5200$ dan nilai $\mathrm{p}=$ 0.0091243 . Kelompok kedua adalah risk taking - visual slow - matic : risk taking visual fast - manual dengan skor diff = 4176.333333, lwr $=309.70922$, upr $=$ 8042.9574, dan $\mathrm{p}=0.0221116$. Kelompok ketiga adalah kelompok risk taking - visual fast - matic : risk averse - visual fast - matic dengan nilai diff $=-5446.856061$, lwr $=$ 9478.09037, upr $=-1415.6218$ dan $\mathrm{p}=$ 0.0008234 . Kelompok keempat adalah risk averse - visual fast - bebek : risk averse visual fast - matic dengan nilai diff = 4932.750000, lwr $=-9564.28561$, upr $=$ 301.2144 dan $\mathrm{p}=0.0259354$. Kelompok kelima terdiri dari risk taking - visual fast bebek : risk averse - visual fast - matic dengan nilai diff $=5660.469697$, lwr $=-9926.72708$, upr $=-1394.2123$. Terakhir, perbandingan mean kelompok subjek risk taking - visual fast - bebek : risk taking - visual slow - matic dan diperolah nilai diff $=-4385.469697$-lwr $=7709.71067$ upr $=-1061.2287$ dan $\mathrm{p}=$ 0.0012597 .

\section{Diskusi}

Sesuai dengan teori dasar dalam psikologi lalu lintas, bahwa secara umum probabilitas intensitas kecelakaan akan naik apabila pengendara memutuskan untuk mendahului kendaraan lain dibandingkan ketika menggunakan kecepatan konstan dan tidak mendahului kendaraan lain. Secara khusus ada faktor internal yang ikut memengaruhi juga, seperti atensi dan kesadaran (Ariana \& Hastjarjo, 2018), kelelahan (Gastaldi, Rossi \& Gecchele, 2014) dan risk taking (Smith, 2016). Fokus pada variabel yang terakhir, dari analisis deskriptif, total sampel dari 23 subjek sebanyak $80 \%$ menyatakan sikap untuk terus menyalip ketika berada di jalan dan ternyata intensi keputusan untuk 
menyalip ini muncul ketika menghadapi kendaraan yang besar seperti truk dan bus. Hasil pertama mengenai karakter risk taking dengan risk averse tidak menemui sesuatu yang baru. Beberapa literatur sudah memaparkan bahwa karakteristik perilaku risk taking memiliki probabilitas untuk mengalami kecelakaan di jalan (Ngueutsa \& Kouabenan, 2017). Semua stimulus yang dipresentasikan untuk mendapatkan ukuran dari fungsi eksekutif spasial dalam kondisi menyalip sebenarnya merupakan gambaran kondisi jalan yang dari beberapa penilaian terbilang penuh, sesak dan ramai, walaupun ada beberapa yang lenggang namun berada di tikungan dan ada marka lurus. Dari sini terlihat bahwa mayoritas subjek tetap mendahului kendaraan lain dan menganggap situasi dalam stimulus adalah sesuatu yang lumrah.

Hasil kedua menunjukkan dalam setiap pemrosesan informasi, kecepatan individu untuk mengenali lebih dari 1 objek dalam sekumpulan objek yang serupa/beragam berkaitan dengan kekuatan atensinya. Di sini ada kerja sama antara visual working memory dan atensi (selective attention), yang mengacu pada tujuan target, derajat beda distraktor dan target dan sejarah bagaimana atensi digunakan (Theeuwes, 2018), di mana menurut peneliti poin terakhir ini erat dengan strategi di masa lalu antara long term memory dengan visual search.

Kecepatan mengenali objek dan meniadakan distraktor sangat penting ketika individu ingin menyalip kendaraan lain. Memori memiliki peran penting dalam membuang distraksi dan fokus mencari target, namun dalam beberapa individu distraksi tidak dibuang begitu saja namun tetap disimpan berada di dalam working memory dan itu mengganggu fokus selanjutnya dalam mencari target stimulus. Fenomena ini disebut sebagai low load capacity (Fukuda \& Vobel, 2009). Peran selektif atensi adalah sebagai gerbang untuk memasukkan informasi yang sesuai dengan intruksi/aturan. Menyalip membutuhkan kecepatan reaksi yang cepat, dari hasil diatas mayoritas subjek dengan tipe fast visual search memiliki high load capacity di mana sanggup meniadakan distraktor dan tetap fokus pada sasaran yaitu kendaran di arah berlawanan.

Hasil ketiga menunjukkan bahwa pada interaksi antara karakter dan tipe visual terbukti bahwa individu dengan kecenderungan risk taking memiliki visual search yang cepat juga. Gambaran individu tersebut sesuai dengan teori bahwa individu yang memiliki karakter risk taking cenderung memasukkan banyak stimulus secara simultan tanpa berpikir panjang, dan itu harus diimbangi dengan visual search yang berubah-ubah juga untuk atensinya. Perilaku tersebut mungkin bisa disebut sebagai perilaku gegabah atau serampangan di jalan raya. Walaupun tidak semua perilaku seperti ini menimbulkan kecelakaan namun hal yang pasti adalah menaikkan peluang untuk kecelakaan di jalan raya.

Interaksi selanjutnya berdasarkan hasil di atas kelompok subjek dengan karakter risk taking, tipe visual fast search dengan motor bebek memiliki fungsi eksekutif yang paling cepat ketika memutuskan untuk menyalip. Diikuti oleh kelompok subjek dengan karakter risk taking, visual fast dan motor matic. Terakhir yang paling lambat adalah kelompok karakter risk averse, tipe visual fast dan motor matic. Kelompok dengan karakter risk taking, tipe visual fast search dan motor bebek diluar dugaan malah memiliki waktu reaksi dari fungsi eksekutif yang paling tinggi dari 6 kelompok diatas. Memang matic tetap mewakili motor dengan tipe yang cepat dan lincah, namun dengan beberapa kejadian baru-baru ini banyak sekali kecelakaan yang terjadi diakibatkan oleh keteledoran dalam 
mengendarai sepeda motor tipe matic. Hal itu memberikan pengetahuan baru kepada para subjek penelitian untuk lebih waspada ketika mengendarai motor tipe matic. Berbeda dengan motor bebek yang tetap ringkas namun bisa bergerak cepat dibandingkan dengan motor manual/sport.

Karakter individu risk taking dan tipe visual fast terpuaskan dengan model motor bebek yang tetap ramping, gesit ketika digunakan untuk menyalip. Penjelasan terakhir, dari kelompok subjek dengan karakter risk averse dan memiliki tipe visual fast dengan motor tipe matic ketika melakukan penyalipan cenderung terlalu lama fungsi eksekutifnya dalam memutuskan, bahkan terlihat ada jeda di jalan. Hal ini juga dianggap sebagai perilaku yang membahayakan di jalan raya apalagi dengan kondisi jalan raya yang penuh sesak.

\section{Kesimpulan}

Penelitian ini dilakukan untuk mengukur fungsi eksekutif ketika berkendara di jalan raya melalui waktu reaksi. Fungsi eksekutif digolongkan ke dalam 3 faktor, yaitu faktor kelompok, faktor visual, dan faktor kendaraan. Kesimpulannya, ada interaksi pada ketiga faktor terhadap waktu reaksi fungsi eksekutif di mana waktu reaksi tercepat dimiliki oleh karakter risk taking, fast visual search dan yang mengendarai motor bebek.

\section{Saran}

Penelitian ini masih sangat awal dan memerlukan banyak sekali perbaikan. Pertama, subjek terbilang tidak proporsional untuk analisis varian. Apalagi untuk faktorial banyak ( $F n)$. Kedua, untuk BART harus melalui uji coba terlebih dahulu sehingga mendapatkan khas dari budaya tertentu. Beberapa subjek juga sangat kaget dan takut melihat balon meletus dan menyelesaikan BART dalam waktu yang lumayan lama. Visual search sebenarnya bisa diukur memakai 3 jenis metode yaitu waktu reaksi, akurasi dan eye tracking, di mana pendekatan di atas merupakan model paling awal. Dari sisi subjek, mungkin bisa dikembangkan dengan memakai subjek dengan umur SMP/SMA yang kemungkinan besar memiliki karakteristik yang berbeda dengan subjek mahasiswa dan umum. Terakhir, kekurangan dari image dapat diganti dengan klip video namun ini membutuhkan cara yang ekstra untuk bisa memasukkan respons ketika video sedang berjalan.

\section{Daftar Pustaka}

Ariana, P. D., \& Hastjarjo, T. D., (2018). Pengaruh perhatian terbagi terhadap kesadaran situasi. Jurnal Psikologi Universitas Diponegoro, 17(1), 87-96. doi: $\underline{10.14710 / j p .17 .1 .87-96}$

Balaguero, M. A., Vicente, M. J., Molina, A. G., Tormos, J. M., \& Rovira, T. R. (2016). Balloon analogue risk task to assess decision-making in acquired brain injury. International Journal of Psychological Research, 9(1), 30-39. doi: $\underline{10.21500 / 20112084.2098}$

Bob, P. (2011). Brain, mind, and consciousness advances in neuroscience research. Germany: Springer Science + Business Media.

Cole, L. (2017). Commercial motor - operation safety. Diunduh dari http://commercialmotor.com

Eckstein, M, P. (2011). Visual search: A retrospective. Journal of Vision, 11(5). doi: $10.1167 / 11.5 .14$

Fukunaga, R., Brown, J. W. \& Bogg, T. (2012). Decision making in the Balloon Analogue Risk Task (BART): Anterior cingulate cortex signals lossaversion but not the infrequency of risky choices. Cognitive Affective $\mathcal{E}$ 
Behavioral Neuroscience, 12(3), 479-90 doi: $10.3758 / \mathrm{s} 13415-012-0102-1$

Fukuda, K., \& Vogel, E. K. (2009). Human variation in overriding attentional capture. Journal of Neuroscience, 29, 8726-8733.

Fuller, R. (2011). Driver control theory from task difficulty homeostasis to risk allostasis. In Porter, B. E. (Ed). Handbook of traffic psychology. (pp. 1318). UK: Academic Press.

Gastaldi, M., Rossi, R. \& Gecchele, G. (2014). Effects of driver task-related fatigue on driving performance. Procedia - Social and Behavioral Sciences, 111, 955-964. doi: 10.1016/j.sbspro.2014.01.130

Groot, K. D. \& Thurik, R. (2018). Disentangling risk and uncertainty: When risk-taking measures are not about risk. Frontiers in Psychology, 9(2194). doi: 10.3389/fpsyg. 2018.02194

Rusmin, A. (2017). Angka kecelakaan lalulintas Indonesia termasuk tinggi di ASEAN. Diunduh dari http://rri.co.id/post/berita/457518/sig ap polri/angka kecelakaan lalulinta s indonesia termasuk tinggi di ase an.html (diakses pada tanggal 9 Januari 2019).

Krause, F., \& Lindemann, O. (2014). Expyriment: A Python library for cognitive and neuroscientific experiments. Behavior Research Methods, 46(2), 416-428.

Leather, N. C. (2009). Risk-taking behavior in adolescence: A literature review. Journal of Child Health Care, 13, 295304. doi: $10.1177 / 13674935093337443$

Lejuez, C. W., Richards, J. B., Read, J. P., Kahler, C. W., \& Ramsey, S. E. (2002). Evaluation of a behavioral measure of risk taking: The Balloon Analogue Risk Task (BART). Journal of Experimental Psychology: Applied, 8(2), 75-84
Li, Q., Qiao, F., Wang, X., \& Yu, L. (2017). Drivers' smart advisory system improves driving performance at STOP sign intersections. Journal of Traffic and Transportation Engineering (English Edition), 4(3), 262-271

Ngueutsa, R., \& Kouabenan, D. R. (2017). Accident history, risk perception and traffic safe behaviour. Ergonomics, 60(9), 1273-1282.

Ma, C., Hao, W., Xiang, W., \& Yan, W. (2018). The impact of aggressive driving behavior on driver-injury severity at highway-rail grade crossings accidents. Journal of Advanced Transportation, 58, 1-10. doi: $\underline{10.1155 / 2018 / 9841498}$

Nugroho, S. A. (2018). Hari pertama simulasi uji psikologi SIM. Diunduh dari https://otomotif.kompas.com/read/20 18/06/21/180500315/hari-pertamasimulasi-uji-psikologi-sim (diakses pada tanggal 10 Januari 2019).

Ott, B. R., Davis, J. D., Papandonatos, G. D., Hewitt S., Festa, E. K., Heindel, W. C., Snellgrove, C. A., \& Carr, D. B. (2013). Assessment of driving-related skills prediction of unsafe driving in older adults in the office setting. Journal of the American Geriatrics Society, 61(7), 1164-1169.

doi: 10.1111/igs.12306.Epub

Pope, C. N., Bell, T. R., \& Stavrinos, D. (2017). Mechanisms behind distracted driving behavior: The role of age and executive function in the engagement of distracted driving. Accident Analysis \& Prevention, 98, 123-129.

doi: 10.1016/j.aap.2016.09.030

Peirce, J., \& MacAskill, M. (2018). Building experiments in PsychoPy. Perception, 48(2). doi: $\underline{10.1177 / 0301006618823976}$

$\mathrm{R}$ Core Team. (2013). R: A language and environment for statistical computing, $R$ foundation for statistical computing. 
Diunduh dari https://www.Rproject.org

Smith, A. P. (2016). A UK survey of driving behaviour, fatigue, risk taking and road traffic accidents. BMJ Open, 6(8). doi: 10.1136/bmjopen-2016-01146

Stephens, A. N., \& Groeger, J. A. (2012). Driven by anger: The causes and consequences of anger during virtual journeys. In Sullman, M. \& Dorn, L. (Eds.). Advances in Traffc Psychology, 1-55. England: Ashgate Publishing Company.

Theeuwes, J. (2018). Visual selection: Usually fast and automatic; seldom slow and volitional; A reply to commentaries. Journal of Cognition, 1(1), 21. doi: 10.5334/joc.32

Trif, V. (2015). Spatial cognition: Theoritical considerations. Procedia - Social and Behavioral Sciences, 187, 168-172.

Van Rossum, (1995). Python founder, Technical report CS-R9526, Centrum voor Wiskunde en Informatica (CWI). Amsterdam.

Wali, B., Ahmed, A., Iqbal, S., \& Hussain, A. (2017). Effectiveness of enforcement levels of speed limit and drink driving laws and associated factors e
Exploratory empirical analysis using a bivariate ordered probit model. Journal of Traffic and Transportation Engineering (English Edition), 4(3), 272-279. doi: $10.1016 / j . j t t e .2017 .04 .001$ Walshe, E. A. I., McIntosh, C.,W., Romer,D. I \& Flaura K. Winston, F. K. (2017). Executive function capacities, negative driving behavior and crashes in young drivers. International Journal of Environmental Research and Public Health, 14(11). doi: 10.3390/ijerph14111314

Wickham, H. (2016). Ggplot2: Elegant graphics for data analysis. New York: Springer-Verlag. Diunduh dari http://ggplot2.org

Wolfe, J. (2018). Visual search. In Wixted, J. T. \& Serences, J. T. (Eds.), Stevens' handbook of experimental psychology and cognitive neuroscience (pp 569-624), Fourth edition. New York : John Wiley \& Sons, Inc. 